\title{
Growth and Potintial of Wireless Internet User in Rural India
}

\author{
Dr. Jasbir Singh \\ Associate Professor, Maharaja Surajmal Institute, Affiliated to GGSIP University, New Delhi-110058 \\ Mobile 9718933600,85871002131 \\ E-mail: jassideswal1974@gmail.com, jasbirdeswal@rediffmail.com
}

\begin{abstract}
Mobile phone is the best friend of the present generation. Mostly people use the smart phone. Smart phone cannot function without internet. So, internet is the primary requirement for the smart phone user. This paper shows the trend of the growth of mobile phone internet user in India, urban area and rural area but it focuses on the growth rate of mobile internet in rural India. This research also found rural area had low growth rate of mobile internet user in compared to India and urban area. Correlation, CAGR and mean analysis is done to find the effects of certain parameters which effects the mobile internet growth in rural India. Paper analysis also finds the correlation with total internet access and rural internet access. Mobile internet growth rate is closely linked with subscription rate through internet mode. More than 60 percent of India's population is living in rural areas. India is called youngest country because more than 40 percent of total population comes in the category of young population. According to some study's in 2019 out of total internet user 38\% internet user are kids which comes in the age group of 15 years and blow. So, youth is a big market for smart phone and use of internet.
\end{abstract}

Key words: Correlation analysis, CAGR, mean analysis, mobile internet, rural India, subscription rate, Tele-density, penetration etc.

\section{Introduction}

Indian economy is called the rural or agriculture economy. At present 68.84 percent people are leaving in rural area. Rural economy has a huge potential of growth. In 2020 due to crona-virus whole world is suffering from Pandemic and growth rate of GDP in India has declined 23.98 percent. At present GDP growth rate came negative. During this Pandemic growth rate of agriculture is more than 3 percent. It is a positive sign for Indian economy. At present (Jan 2020) 696.77 million people are using the internet. It is estimated that upto 2025, 974.86 million people will be internet user in India. India comes in top 20 internet user countries. In 2018 out of 100 people 38 were using the internet. While in the same time period in whole world out of 100 people 51 people were using the internet. Highest number of people out of 100 people 80 people in
Europe was using the internet while lowest number 24 people out of 100 people were using the internet in Africa in same time period. Due to work from home use of internet is increasing more and more in Pandemic.

In 2019, 420.70 million people were using the phone internet and it is estimated that this number in 2023 will be increased 500.90 million. In the same time period out of 1161.71 million phone internet user, 669.14 million people in urban area and 514.27 million people are using the phone internet in rural area. At present out of total internet user 55 percent male and 45 percent female are using the internet in India. According to 2019 tele-density of internet user per 100 in India is 90.10 and mobile internet user is 88.45 per 100 people. While this tele-density per 100 people in urban area is 159.66 people while in rural area it is 57.50 people. It shows the less 
growth rate of rural internet user in comparison to urban area. In rural India growth rate of monthly active internet user is estimated $45 \%$ for the year 2020 while it is estimated for urban people 11 percent in India. Out of total internet user 38\% internet user are kids who come in the age group of 15 years and blow. It happened due to local language software and video key driver for the booming in the rural internet growth. Children and housewives in rural area will be the new internet adopters in the next one or two year. In the rural India out of total internet user $84 \%$ users access the internet for entertainment purposes.

A huge number of people live in rural India and majority of population living without internet. So we can say that there is a huge possibility to increase the internet user in rural India. But there is a big problem of poor infrastructure in rural India. Due to less supply of power and less speed of bandwidth the internet connectivity remain low in rural internet penetration. Another block is lack of affordable computer systems and internet connections due to rural people's low income. On an average a farmer family in which on an average minimum five person are living whose per month income on current prices is 6500 rupees. In comparison to developed countries, India's literacy rate is still very low $(77.7 \%$ in year 2020$)$ and it is very much low (73.5\% in year 2020) in rural areas. According to Indian constitution, 22 official languages and a lot off unofficial and local languages useas.

\section{Review of literature}

According to M. Prabu and R. Manoov in their study 'Analyzing the impact of Internet in rural India' found that, rural internet growth is not related to urban internet growth. Study found that, as rural subscriber rate increases the rural internet growth also increase. Study also found that urban internet users mostly use wireless mode to access internet.
Kathait and Singh, 2014 found their report that more teenagers are attracted towards internet and the reasons are;

(a) Students have a lot off blocks to spent times,

(b) Various schools and universities provide the free access of internet,

(c) Students between age group of 18-22 years those are away from parental first time and out of parental control are not in monitoring mostly times they remain online.

(d) Young students those have no experience of hostel and university life they have to face new problems to adapting hostel and university life. In this age when they make new friends especially opposite sex and seeking a companion they use different social network applications which required the internet.

(e) Due to COVID-19 students have to attend the online classes and have to submit the assignment and answer sheet and receive full encouragement from faculty and administrators through using the different mobile applications.

(f) Adolescents are more trained to use the different applications of technological inventions which trained to use the different applications for technological inventions they required the access of internet.

(g) Students explore the university sources to remove the stress, to pass exams in a essays and complete their degrees in the prescribed time with reasonable marks.

(h) Students feel that university life is alienated from social life and activities. After finishing their studies when they goes in the job market with all its uncertainties they must participate and succeed in finding employment through internet.

According to Sandhya Keelery, July 7 2020, in the report 'Internet usages in India- Statistics \& Facts' found that data usage per Smartphone per month will triple $21 \mathrm{~EB}$ per month (one billion GB) by 2025. On an average Indian used around 12 GB data monthly. It is highest consumption globally. 
It is projected that use of data by 2025 may be increased around $25 \mathrm{~GB}$ per month.

\section{Research Methodology:}

Present paper is totally based of secondary data. Secondary data has been collected from various sources like: TARI\& Telecom Statistics India 2019. In the present study data analysis through chart, mean value, growth value, percentage methods and correlation methods etc.

\section{Hypotheses:}

H1: Total internet growth is related to rural internet growth.

H2: Rural internet growth is not related to urban internet growth.

H3: Internet growth rate is related to mobile internet growth.

H4: India's internet growth rate is not correlated with World internet growth.

$$
r_{x y}=\frac{\sum_{i=1}^{n}\left(x_{i}-\bar{x}\right)\left(y_{i}-\bar{y}\right)}{\sqrt{\sum_{i=1}^{n}\left(x_{i}-\bar{x}\right)^{2} \sum_{i=1}^{n}\left(y_{i}-\bar{y}\right)^{2}}}
$$

Correlation method, Correlation coefficient. Here $\mathrm{x}_{\mathrm{i}}$ is rural area, $\mathrm{y}_{\mathrm{i}}$ is urban area.

Here $x_{i}$ is Rural Subscribers, $y_{i}$ is Urban Subscribers.

Compound Annual Growth Rate (CAGR) = (Current Value /Base Value) $^{1 / n}-1$

$\mathrm{n}=$ number of years, End= Current Value, Start= Base Value

Table no 1 show that there is a significant correlation 0.989 at $0.05 \%$ between India \& world Mobile internet user. Table shows that mean value of individual internet user during the study period is highest in Europe (69.27\%) and lowest in the India (12.82\%). Mobile internet user per 100 in the developed countries is 2.46 times greater (72.45\%) than developing countries (29.45\%) during the study period. Study found that growth rate of Mobile internet user in India is calculated
$16.62 \%$ in the world followed to Africa (17.69\%) and it is greater than the growth rate of world (7.5\%), developed countries $(2.61 \%)$ and under developing countries (11.19\%).

Table no 2 depicts that mobile internet subscriptions per 100 in the world is highest in CIS (132.55\%) and lowest in Africa (59.73\%). Table also shows that mobile internet subscriptions per 100 in the developed countries are 1.45 times greater (119\%) than developing countries (82.27\%). While in India 68.09 percentage people are using the mobile internet, it is less than the World mobile internet user $(88.73 \%)$. Study found that growth rate of mobile internet subscriptions in India is calculated highest $10.5 \%$ in the world and it is greater than the growth rate of world $(5.40 \%)$, developed countries $(1.56 \%)$ and under developing countries $(6.99 \%)$.

Table no 3 shows that there is significant correlation 0.951 at $0.01 \%$ (2-tailed) between mobile internet subscription rate and social network subscription rate. Table depicts that there is significant correlation 0.995 at $0.01 \%$ (2-tailed) between mobile internet subscription rate and social network subscription rate. Table also shows that there is significant correlation 0.969 at $0.01 \%$ (2-tailed) between internet subscription rate and mobile internet subscription rate. Study found that growth rate of internet user, mobile internet user, social network user and face-book users are $12.55 \%, 8.37 \%, 13.59 \%$ \& $14.09 \%$ during the study period respectively.

Table show that there is a significant correlation 0.986 at $0.01 \%$ (2-tailed) between social network user and face-book user. Table also show that there is a significant correlation 0.992 at $0.01 \%$ (2-tailed) between face-book and mobile internet subscription rate. Another, table show that there is a significant correlation 0.995 at $0.01 \%$ (2-tailed) between mobile internet subscription rate and social network subscription rate.

Chart no 1: Shows that in the big cities in India highest mobile internet subscribers in 2019 came 
(11.7 millions) from Mumbai and lowest came from the Pune (3.6 Millions).

Chart no 2: Shows that mobile internet penetration rate in India was 4.4 percent in 2008 which has increased 48.48 percent in 2019.

Chart no 3: Depicts that social penetration rate in India was 19.13 percent in 2015 which may be increased 67.4 percent in 2025.

Table no 4 shows that on all India level 67 percent male and 33 percent female are using the Mobile internet. While 62 and 72 percent male and 38 and 28 percent female are using the mobile internet in urban and rural areas in December 2019 respectively.

Table no 5 depicts that on all India level, urban area and rural have the highest percent $(35,33 \&$ $37 \%$ ) of mobile internet user comes from the age group 20-29 years and lowest mobile internet user $(6,8 \& 3 \%)$ comes from the age group of above 50 years respectively.

Table no 6 depicts that frequency of mobile internet user in all India level, urban areas and rural areas have the highest percent $(65,72 \&$ $57 \%$ ) of mobile internet user comes from the categories everyday user respectively. While, lowest mobile internet user (4\%) comes from the categories 4-5 days in a week user.

Table no 7 depicts that there is a significant correlation 0.989 at $0.01 \%$ (2-tailed) between number of mobile internet user and Rural India. There is no correlation between rural and urban areas. There is a significant correlation 0.986 at $0.05 \%$ between urban areas and wireless internet user. There is also a significant correlation 0.989 at $0.05 \%$ between rural areas and wireless internet user.

Study also found that growth rate of mobile internet user, wireless internet user, mobile internet user in urban areas, mobile internet user rural areas, public sector internet user and private internet users are 12.10, 13.25, 9.55, 17.21, 4.41 \& 13.87 percent during the study period respectively. While during the same time period growth rate of wire-line is negative $(-4.85 \%)$.

Table no 8 depicts that Tele-density Correlation is significant 0.950 at $0.05 \%$ between total mobile internet subscription and rural areas. Tele-density Correlation is significant 0.893 at $0.05 \%$ between total mobile internet subscription and urban areas. There is significant Correlation 0.961 at $0.05 \%$ for Tele-density between total mobile internet user in urban areas and wireless internet user. There also significant Correlation 0.982 at $0.05 \%$ for Teledensity between total mobile internet user in rural areas and wireless internet user. Study also found that growth rate of Tele-density, wireless, urban, rural, public and private sector's internet user are $10.83,11.97,7.59,16.23,3.23 \& 19.69$ percent during the study period respectively. While during the same time period growth rate of wire-line is negative $(-5.94 \%)$.

Table no 9 explain that there is significant Correlation 0.610 at $0.05 \%$ between mobile internet user in rural and urban areas. There also significant correlation 0.626 at $0.05 \%$ for Teledensity between mobile internet user in rural and urban areas.

Table no 10 depicts that according to service area wise average mobile internet subscriptions in Rural India is highest in UP east (14.51) and lowest in J\&K (2.00) from 2015 to 2019. Study find that highest growth rate of mobile internet user during the study period comes in Mumbai (37.08\%) while lowest growth rate comes in Delhi $(-7.25 \%)$ that is negative.

\section{Result and discussion \\ Hypothesis Testing}

H1: Total internet growth is related to rural internet growth.

There is a significant correlation 0.989 at $0.01 \%$ (2-tailed) between number of mobile internet user and Rural India. Tele-density correlation is also significant 0.950 at $0.05 \%$ between mobile 
internet subscription and rural areas. So study found that $\mathrm{H} 1$ is true.

H2: Rural mobile internet user growth is not related to urban mobile internet user growth.

There is no correlation between rural and urban areas. So study found that $\mathrm{H} 2$ is true.

H3: Internet growth rate is related to mobile internet growth rate.

There is significant correlation 0.969 at $0.01 \%$ (2tailed) between total internet subscription rate and mobile internet user subscription rate. So study found that $\mathrm{H} 3$ is true.

H4: India's total mobile internet user growth rate is not correlated with World's mobile internet user growth rate.

There is a significant correlation 0.989 at $0.05 \%$ between Indian mobile internet user \& world mobile internet user. So study found that $\mathrm{H} 4$ is false.

Study found that growth rate of mobile internet user in India is $10.5 \%$ that is highest in the world. Study found the discrimination in the user of mobile internet user according to gender, age group and area wise. Study shows that during the study period growth rate of Number of Face book user, Social Network user \& Mobile Internet users in India came $14.09 \%, 13.59 \%$ and $8.37 \%$ respectively. In rural India only 28 percent female are using the mobile internet in comparison to 33 percent female in all India level. In the rural areas highest mobile internet user $(37 \%)$ comes in the age group of 20-29 years. Only 57 percent rural population is using the internet. It is less than all India (65\%) and urban (72\%) population. Growth rate of rural mobile internet user is calculated 17.21 percent that is highest in comparison to all India $(12.10 \%)$ and urban areas $(9.55 \%)$. Teledensity growth rate of mobile internet user in rural areas is calculated (16.33\%) which is greater than all India mobile internet user growth rate $(10.83 \%)$ and urban mobile internet user growth rate $(7.59 \%)$.

Based on the correlation analysis done above, we have observed significance correlation between certain variables except between rural mobile internet user and urban mobile internet user. This analysis shows that face-book user and social network users showing more importance to Internet. Another result shows that female and youth contribution is not satisfactory in internet user especially in rural areas. We can say that internet facility can improve their wealth, health and job opportunity especially in rural areas. Anyway there is some lacking in internet development in Rural India. There are various reasons behind not using the internet services by people in rural areas. The reasons are less income, lack of knowledge of Internet, lack of infrastructure, lack of electricity supply and beliefs (personal opinions). Majority of female in rural areas cannot access internet because they are not working, they are less educated and they do not have an internet connection at home.

\section{Conclusion}

The calculated correlation value shows us high correlation between Mobile Phone Internet Subscribers and Face-book \& Social Network subscribers in rural areas. It also shows the same positive vale between Social Network subscribers and Face-book that means there is correlation between them. India is a very fast growing market for the latest technology offerings. It has a huge potential for internet growth especially in rural areas. Contribution of rural population and female in rural as well as urban are very less. Demand of such people has also played vital role in the growth of Indian economy during the CRONA-19, work from home and online classes. As we have analyzed the up-word trend in the growth of internet access rate, creating social networking application in Hindi and regional languages will enable greater growth of internet use in rural India. Getting the Web-series for youth and women, online coaching classes, special application for students and teen-ager in their 
mother tongue is necessary; Internet could be a driver for immense business growth in rural India as well as urban India. Work from Home and online teaching and online coaching classes, online banking, mobile payment apps, games of children, special apps for students and professionals also play a dominant role in the growth and frequency of internet in rural India as well as urban India. Indian government as well as IT researchers should recognize this as potential and they should take effort to build applications and good infrastructure to rural as well as urban Indian population.

Table No1: Individual Internet User in World per 100 People from 2008 to 2018

\begin{tabular}{|l|l|l|l|l|l|l|l|l|l|l|}
\hline Year & World & Developed & Developing & India & Africa & $\begin{array}{l}\text { Arab } \\
\text { States }\end{array}$ & $\begin{array}{l}\text { Asia \& } \\
\text { Pacific }\end{array}$ & CIS & Europe & America \\
\hline 2008 & 23 & 61 & 14 & 7 & 4 & 19 & 16 & 21 & 57 & 44 \\
\hline 2009 & 25 & 63 & 17 & 11 & 5 & 21 & 19 & 24 & 60 & 46 \\
\hline 2010 & 29 & 67 & 21 & 16 & 7 & 24 & 22 & 36 & 63 & 49 \\
\hline 2011 & 31 & 68 & 23 & 34 & 8 & 27 & 25 & 43 & 65 & 51 \\
\hline 2012 & 34 & 72 & 26 & 39 & 10 & 30 & 28 & 54 & 67 & 55 \\
\hline 2013 & 37 & 74 & 29 & 13 & 12 & 33 & 31 & 59 & 71 & 56 \\
\hline 2014 & 40 & 76 & 32 & 20 & 14 & 36 & 34 & 62 & 72 & 58 \\
\hline 2015 & 43 & 76 & 36 & 24 & 18 & 40 & 38 & 63 & 74 & 62 \\
\hline 2016 & 46 & 79 & 39 & 27 & 20 & 43 & 41 & 66 & 76 & 65 \\
\hline 2017 & 49 & 80 & 42 & 33 & 22 & 49 & 44 & 69 & 77 & 68 \\
\hline 2018 & 51 & 81 & 45 & 38 & 24 & 55 & 47 & 71 & 80 & 70 \\
\hline Mean & 37.09 & 72.45 & 29.45 & 12.82 & 13.09 & 34.27 & 31.36 & 51.6 & 69.27 & 56.73 \\
\hline Total & 408 & 797 & 324 & 262 & 144 & 377 & 345 & 568 & 762 & 624 \\
\hline $\begin{array}{l}\text { CAG } \\
\text { R }\end{array}$ & 7.5 & 2.61 & 11.19 & 16.62 & 17.69 & 10.14 & 10.29 & 11.7 & 3.13 & 4.31 \\
\hline
\end{tabular}

Source: ITU website, TARI\& Telecom Statistic India 2019.

Table No 2: Mobile Internet Subscriptions in World per 100 People from 2008 to 2018

\begin{tabular}{|l|l|l|l|l|l|l|l|l|l|l|}
\hline Year & World & Developed & Developing & India & Africa & $\begin{array}{l}\text { Arab } \\
\text { States }\end{array}$ & $\begin{array}{l}\text { Asia \& } \\
\text { Pacific }\end{array}$ & CIS & Europe & America \\
\hline 2008 & 60 & 108 & 49 & 29 & 32 & 63 & 47 & 110 & 117 & 81 \\
\hline 2009 & 68 & 112 & 58 & 43 & 38 & 76 & 56 & 129 & 117 & 87 \\
\hline 2010 & 77 & 113 & 69 & 61 & 44 & 88 & 67 & 137 & 115 & 94 \\
\hline 2011 & 84 & 113 & 78 & 71 & 52 & 96 & 77 & 129 & 118 & 101 \\
\hline 2012 & 88 & 116 & 83 & 68 & 58 & 102 & 81 & 130 & 120 & 104 \\
\hline 2013 & 93 & 118 & 88 & 69 & 65 & 107 & 86 & 135 & 122 & 108 \\
\hline 2014 & 97 & 122 & 91 & 73 & 70 & 106 & 90 & 136 & 121 & 112 \\
\hline 2015 & 97 & 125 & 92 & 76 & 75 & 105 & 92 & 138 & 120 & 112 \\
\hline 2016 & 101 & 127 & 95 & 85 & 73 & 102 & 99 & 139 & 121 & 112 \\
\hline 2017 & 104 & 127 & 99 & 87 & 74 & 102 & 104 & 138 & 120 & 112 \\
\hline
\end{tabular}


PSYCHOLOGY AND EDUCATION (2021) 58(2): 1010-1022

An Interdisciplinary Journal

Article Received: 16th October, 2020; Article Revised: 30th December, 2020; Article Accepted: 08th January, 2021

\begin{tabular}{|l|l|l|l|l|l|l|l|l|l|l|}
\hline $2018 *$ & 107 & 128 & 103 & 87 & 76 & 103 & 110 & 137 & 120 & 113 \\
\hline Total & 976 & 1309 & 905 & 749 & 657 & 1050 & 909 & 1458 & 1311 & 1136 \\
\hline Mean & 88.73 & 119 & 82.27 & $\begin{array}{l}68.0 \\
9\end{array}$ & 59.73 & 95.45 & 82.64 & $\begin{array}{l}132.5 \\
5\end{array}$ & 119.18 & 103.27 \\
\hline $\begin{array}{l}\text { CAG } \\
\text { R }\end{array}$ & 5.40 & 1.56 & 6.99 & $\begin{array}{l}10.5 \\
0\end{array}$ & 8.18 & 4.57 & 8.04 & 2.02 & 0.23 & 3.07 \\
\hline
\end{tabular}

Source: ITU website, TARI\& Telecom Statistic India 2019.

*Estimated Data

Table no3: Number of Mobile Internet users in India from 2015 to 2020 with a forecast until 2023 (in Millions)

\begin{tabular}{|l|l|l|l|l|}
\hline Year & Internet User & $\begin{array}{l}\text { Mobile Phone } \\
\text { Internet User }\end{array}$ & $\begin{array}{l}\text { Social Network } \\
\text { User }\end{array}$ & Face-book User \\
\hline 2015 & 302.36 & 242.92 & 142.23 & 135.6 \\
\hline 2016 & 342.65 & 281.81 & 168.10 & 165.57 \\
\hline 2017 & 422.20 & 361.60 & 296.30 & 248.3 \\
\hline 2018 & 493.96 & 390.90 & 326.10 & 281.0 \\
\hline 2019 & 636.73 & 420.70 & 351.40 & 313.6 \\
\hline 2020 & 696.77 & 448.20 & 376.10 & 346.2 \\
\hline 2021 & 761.29 & 469.30 & 400.30 & 378.9 \\
\hline 2022 & 820.99 & 486.70 & 422.70 & 411.5 \\
\hline 2023 & 876.25 & 500.90 & 447.90 & 444.2 \\
\hline Mean & 594.8 & 400.34 & 325.68 & 302.76 \\
\hline CAGR & 12.55 & 8.37 & 13.59 & 14.09 \\
\hline
\end{tabular}

Source: TARI\& Telecom Statistics India 2019

NA: Data not Available.

Chart No 1: Number of Mobile Internet users in Big Cities in India as on $31^{\text {st }}$ March 2019 (in Millions)

Number of internet users in Big Cities in India, in Millions

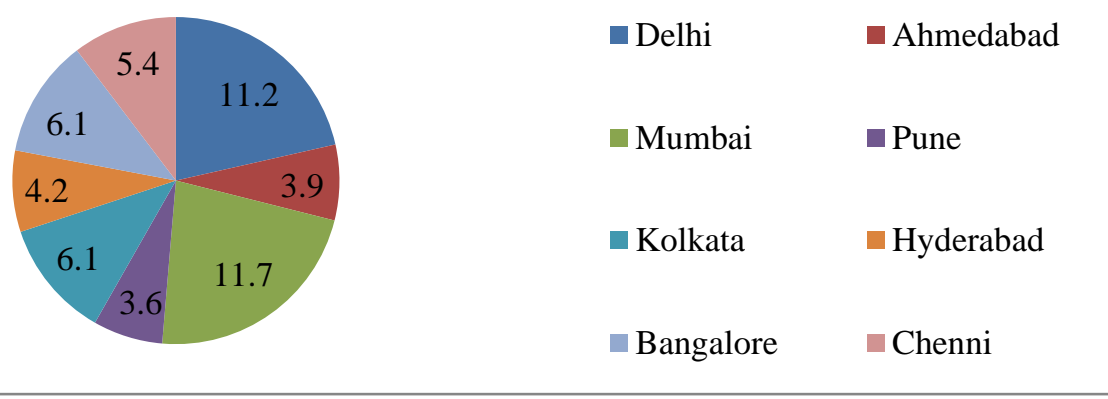

Source: TARI\& Telecom Statistics India 2019 
Chart No 2: Mobile Internet penetration rate in India from 2008 to 2020

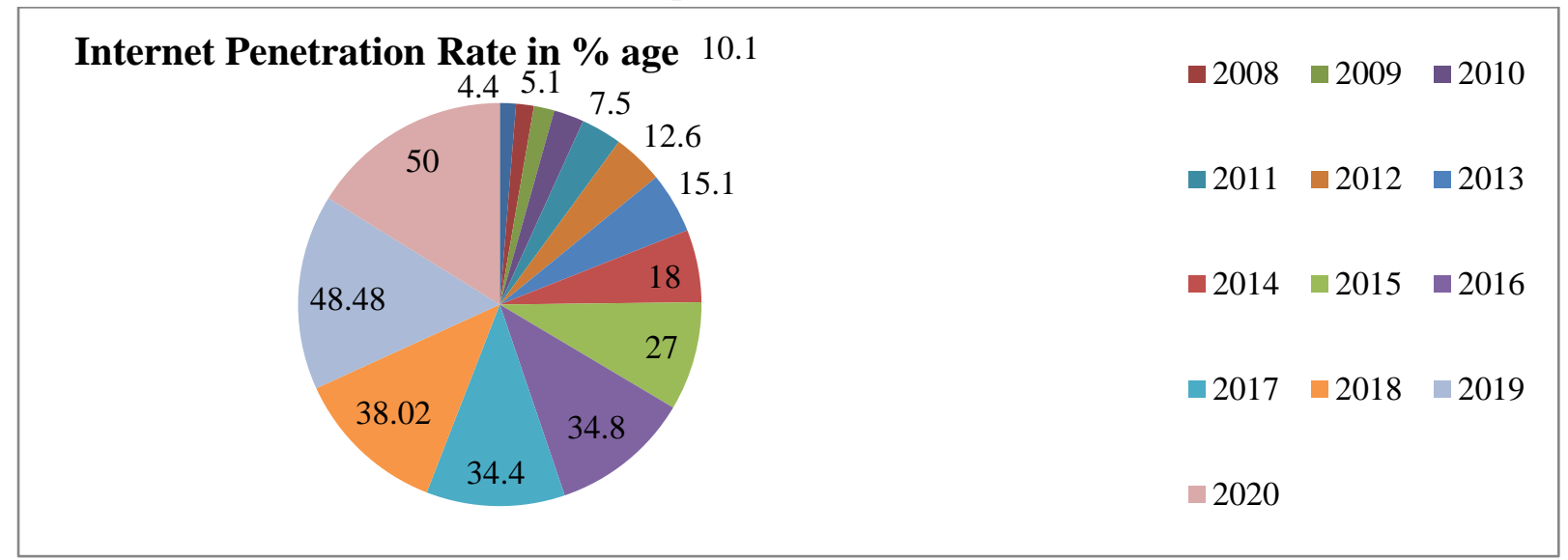

Source: TARI\& Telecom Statistic India 2019.

Chart No 3: Mobile Internet penetration rate in India from 2015 to 2025

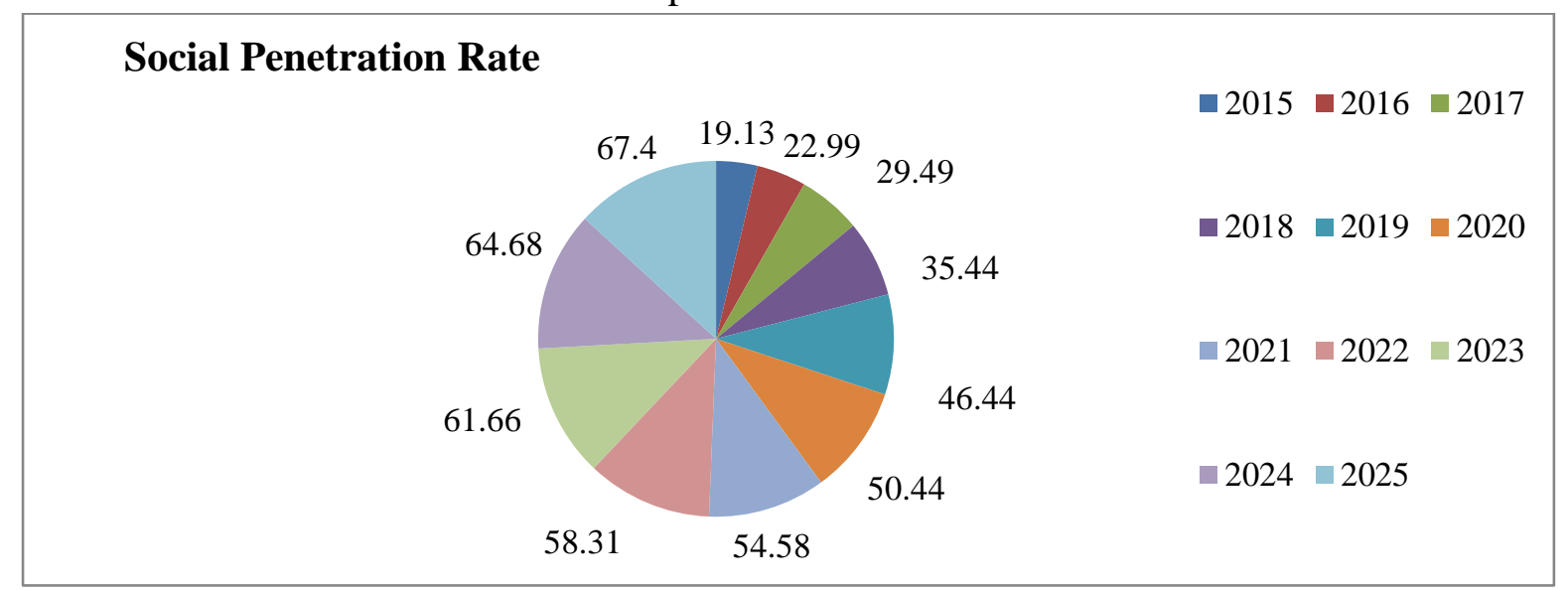

Source: TARI\& Telecom Statistic India 2019.

Table No 4: Distribution of Mobile Internet user by Gender in \% age as on Dec 2019

\begin{tabular}{|l|l|l|l|}
\hline & Male & Female & Total \\
\hline All India & 67 & 33 & 100 \\
\hline Urban & 62 & 38 & 100 \\
\hline Rural & 72 & 28 & 100 \\
\hline
\end{tabular}

Source: TARI\& Telecom Statistic India 2019. 
Chart No-4: Distribution of Internet user by Gender and by area wise in India as on Dec. 2019 (in \% age)

Mobile Internet user by Gender and by area wise in India as on Dec. 2019 (in \% age)

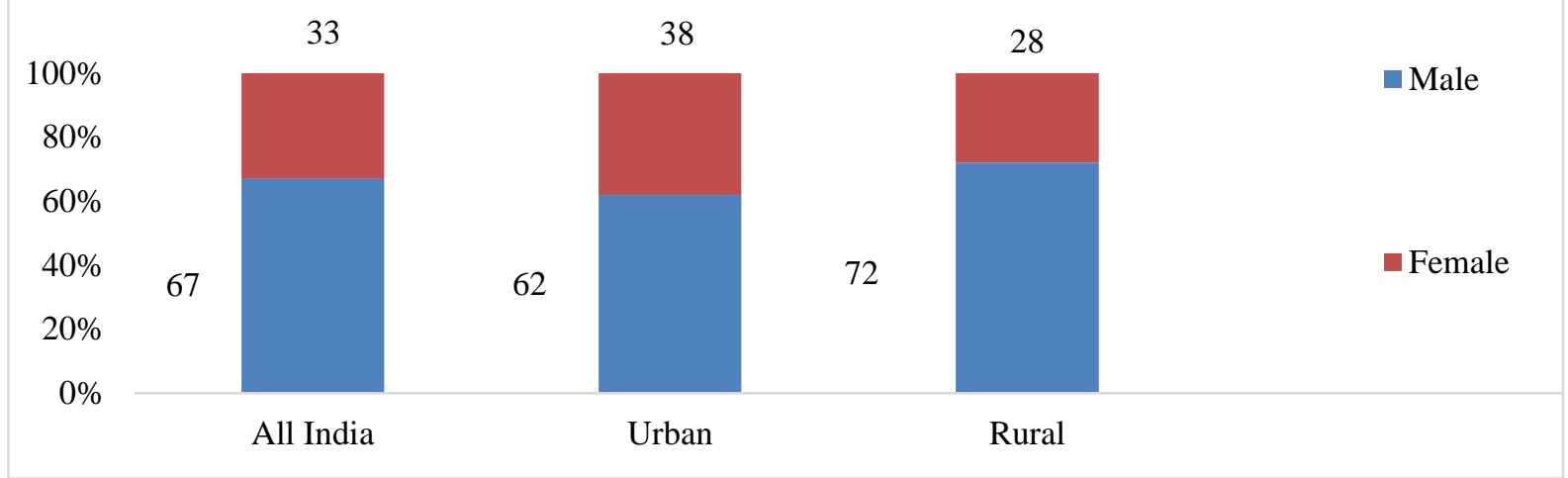

Source: DOT compiled data, TARI\& Telecom Statistic India 2019.

Table No 5: Distribution of Mobile Internet user by Age group in \% age as on Dec 2019

\begin{tabular}{|l|l|l|l|l|l|l|}
\hline & $\begin{array}{l}12-15 \\
\text { Year }\end{array}$ & $16-19$ Year & 20-29 Year & $\begin{array}{l}30-39 \\
\text { Year }\end{array}$ & $\begin{array}{l}40-49 \\
\text { Year }\end{array}$ & $\begin{array}{l}\text { More } \\
\text { than 50 } \\
\text { year }\end{array}$ \\
\hline All India & 14 & 18 & 35 & 19 & 9 & 6 \\
\hline Urban & 12 & 14 & 33 & 21 & 11 & 8 \\
\hline Rural & 15 & 21 & 37 & 17 & 7 & 3 \\
\hline
\end{tabular}

Source: DOT compiled data, TARI\& Telecom Statistic India 2019.

Chart No-5: Distribution of Mobile Internet user by Age group in India as on Dec 2019 (in \% age)

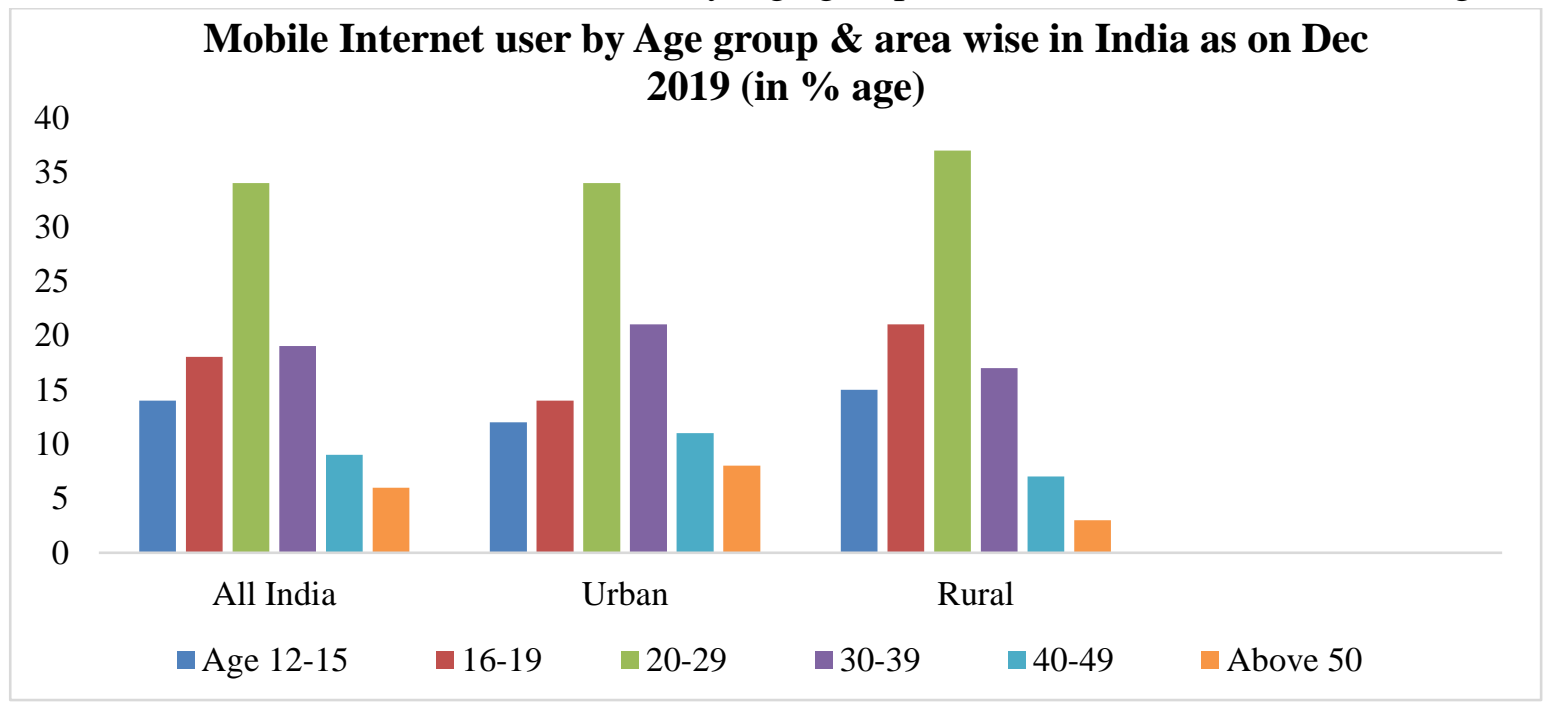

Source: DOT compiled data, TARI\& Telecom Statistic India 2019.

Table No 6: Frequency of Mobile Internet users by Regions in \% age as on Dec 2019

\begin{tabular}{|l|l|l|l|l|l|l|}
\hline & $\begin{array}{l}\text { Every } \\
\text { Day }\end{array}$ & $\begin{array}{l}4-5 \text { Day } \\
\text { in Week }\end{array}$ & $\begin{array}{l}\text { 1-3 Day in } \\
\text { Week }\end{array}$ & $\begin{array}{l}\text { Once a } \\
\text { Week }\end{array}$ & $\begin{array}{l}\text { Less often than Once a } \\
\text { Week }\end{array}$ & Total \\
\hline All India & 65 & 04 & 11 & 07 & 13 & 100 \\
\hline
\end{tabular}


Article Received: 16th October, 2020; Article Revised: 30th December, 2020; Article Accepted: 08th January, 2021

\begin{tabular}{|l|l|l|l|l|l|l|}
\hline Urban & 72 & 04 & 09 & 05 & 09 & 100 \\
\hline Rural & 57 & 04 & 13 & 09 & 17 & 100 \\
\hline
\end{tabular}

Source: DOT compiled data, TARI\& Telecom Statistic India 2019.

Chart No-6: Frequency of Mobile Internet users in India as on Dec 2019 (in \% age)

Frequency of Internet users in India as on Dec 2019 (in \% age)

80

60

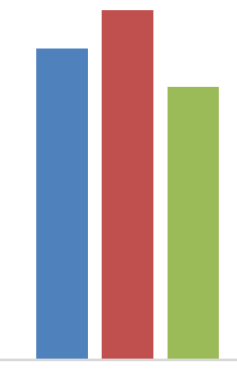

Every Day

4-5 Day in Week 1-3 Day in Week

Once a Week

Oftenly

Source: DOT compiled data, TARI\& Telecom Statistic India 2019.

Table No 7: Area-wise \& Sector-wise No of Mobile Internet user in India from 2008 to 2019 (In Millions)

\begin{tabular}{|l|l|l|l|l|l|l|l|}
\hline Year & No of Phone & Wireless & Wire-line & Urban & Rural & Public & Private \\
\hline 2008 & 300.49 & 261.08 & 39.41 & 223.99 & 76.50 & 79.55 & 220.94 \\
\hline 2009 & 429.72 & 391.76 & 37.96 & 306.21 & 123.51 & 89.55 & 340.18 \\
\hline 2010 & 621.28 & 584.32 & 36.96 & 420.51 & 200.77 & 105.87 & 515.41 \\
\hline 2011 & 846.33 & 811.6 & 34.73 & 564.04 & 282.29 & 126.00 & 720.33 \\
\hline 2012 & 951.35 & 919.18 & 32.17 & 620.52 & 330.83 & 130.27 & 821.08 \\
\hline 2013 & 898.02 & 867.81 & 30.21 & 548.80 & 349.21 & 130.11 & 767.91 \\
\hline 2014 & 933.02 & 904.52 & 28.50 & 555.23 & 377.78 & 120.05 & 812.96 \\
\hline 2015 & 996.13 & 969.54 & 26.59 & 580.05 & 416.08 & 100.34 & 895.79 \\
\hline 2016 & 1059.33 & 1034.11 & 25.22 & 611.56 & 447.77 & 108.65 & 950.68 \\
\hline 2017 & 1194.99 & 1170.59 & 24.40 & 693.18 & 501.81 & 122.18 & 1072.81 \\
\hline 2018 & 1211.80 & 1188.99 & 22.81 & 685.93 & 525.87 & 131.66 & 1080.14 \\
\hline 2019 & 1183.14 & 1161.71 & 21.70 & 669.14 & 514.27 & 133.51 & 1049.90 \\
\hline Mean & 885.47 & 855.42 & 30.06 & 539.93 & 345.56 & 114.81 & 770.68 \\
\hline Total & 10625.6 & 10265.0 & 360.66 & 6479.16 & 4146.69 & 1377.74 & 9248.13 \\
\hline CAGR & 12.10 & 13.25 & -4.85 & 9.55 & 17.21 & 4.41 & 13.87 \\
\hline
\end{tabular}

Source: TARI\& Telecom Statistic India 2019. 
Table No 8: Area-wise \& Sector-wise Tele-density of Mobile Internet User in India from 2008 to 2019 (per 100)

\begin{tabular}{|l|l|l|l|l|l|l|l|}
\hline Year & $\begin{array}{l}\text { Tele- } \\
\text { density }\end{array}$ & Wireless & Wire-line & Urban & Rural & Public & Private \\
\hline 2008 & 26.22 & 22.78 & 3.44 & 66.39 & 9.46 & 6.94 & 19.28 \\
\hline 2009 & 36.98 & 33.71 & 3.27 & 88.84 & 15.11 & 7.71 & 29.27 \\
\hline 2010 & 52.74 & 49.60 & 3.14 & 119.45 & 24.31 & 8.99 & 43.75 \\
\hline 2011 & 70.89 & 67.98 & 2.91 & 156.93 & 33.83 & 10.55 & 60.34 \\
\hline 2012 & 78.66 & 76.00 & 2.66 & 169.17 & 39.26 & 10.77 & 67.89 \\
\hline 2013 & 73.32 & 70.85 & 2.47 & 146.64 & 41.05 & 10.62 & 62.69 \\
\hline 2014 & 75.23 & 72.94 & 2.30 & 145.46 & 44.01 & 9.68 & 65.55 \\
\hline 2015 & 79.36 & 77.24 & 2.12 & 149.04 & 48.04 & 7.99 & 71.36 \\
\hline 2016 & 83.40 & 81.41 & 1.99 & 154.18 & 51.26 & 8.55 & 74.85 \\
\hline 2017 & 93.01 & 91.11 & 1.90 & 171.52 & 56.98 & 9.51 & 83.50 \\
\hline 2018 & 93.27 & 91.51 & 1.76 & 166.64 & 59.25 & 10.13 & 83.14 \\
\hline 2019 & 90.10 & 88.45 & 1.65 & 159.66 & 57.50 & 10.16 & 79.94 \\
\hline Mean & 71.10 & 68.63 & 2.47 & 141.16 & 40.01 & 9.30 & 61.80 \\
\hline Total & 853.18 & 823.58 & 29.61 & 1693.92 & 480.06 & 111.6 & 741.56 \\
\hline CAGR & 10.83 & 11.97 & -5.94 & 7.59 & 16.23 & 3.23 & 19.69 \\
\hline
\end{tabular}

Source: TARI\& Telecom Statistic India 2019.

Table No 9: Service Area wise no of Mobile Internet Subscriber in India from 2008 to 2019 (Share In \% age\& Tele-density per 100)

\begin{tabular}{|l|l|l|l|l|l|l|}
\hline \multicolumn{4}{|l|}{ \% age Share } & \multicolumn{3}{l|}{ Tele-density Per 100 } \\
\hline Name & Total & Urban & Rural & Total & Urban & Rural \\
\hline Andhra Pradesh & 6.82 & 7.33 & 7.57 & 80.98 & 161.83 & 43.20 \\
\hline Assam & 1.65 & 1.22 & 2.36 & 47.53 & 131.83 & 31.88 \\
\hline Bihar & 6.5 & 5.41 & 8.65 & 39.58 & 149.86 & 27.44 \\
\hline Gujarat & 5.97 & 6.13 & 5.87 & 84.76 & 129.74 & 48.56 \\
\hline Haryana & 2.32 & 2.05 & 2.84 & 75.45 & 118.10 & 52.49 \\
\hline Himachal Pradesh & 0.87 & 0.53 & 1.43 & 110.79 & 362.21 & 78.16 \\
\hline Jammu \& Kashmir & 0.88 & 0.79 & 1.05 & 65.59 & 127.60 & 42.08 \\
\hline Karnataka & 6.12 & 7.00 & 4.65 & 87.34 & 160.98 & 41.92 \\
\hline Kerala & 3.95 & 3.44 & 5.01 & 95.28 & 204.07 & 58.22 \\
\hline Madhya Pradesh & 5.77 & 5.62 & 5.96 & 51.36 & 111.06 & 29.20 \\
\hline Maharashtra & 7.92 & 7.13 & 9.36 & 72.09 & 111.36 & 50.46 \\
\hline North East & 0.97 & 0.89 & 1.12 & 38.61 & 143.50 & 39.18 \\
\hline Odisha & 2.65 & 2.02 & 3.70 & 57.80 & 152.32 & 38.06 \\
\hline Punjab & 3.47 & 3.58 & 3.43 & 98.86 & 148.10 & 62.18 \\
\hline Rajasthan & 5.52 & 4.64 & 7.07 & 68.71 & 146.69 & 44.00 \\
\hline Tamil Nadu & 7.71 & 9.06 & 5.66 & 100.91 & 130.76 & 64.86 \\
\hline Utter Pradesh & 13.25 & 11.80 & 14.26 & 49.32 & 117.83 & 29.34 \\
\hline
\end{tabular}


Article Received: 16th October, 2020; Article Revised: 30th December, 2020; Article Accepted: 08th January, 2021

\begin{tabular}{|l|l|l|l|l|l|l|}
\hline West Bengal & 4.56 & 2.76 & 7.55 & 53.21 & 134.36 & 39.63 \\
\hline Kolkata & 2.64 & 3.91 & 0.49 & 145.77 & $\#$ & $\#$ \\
\hline Chennai* & 2.26 & 3.17 & 0.09 & 136.02 & 134.61 & $\#$ \\
\hline Delhi & 5.01 & 7.75 & 0.40 & 213.92 & $\#$ & $\#$ \\
\hline Mumbai & 4.0 & 6.29 & 0.19 & 150.24 & $\#$ & $\#$ \\
\hline Total & 100.81 & 102.52 & 98.71 & 1924.12 & 2876.81 & 820.86 \\
\hline
\end{tabular}

\#: Rural- Urban Breakup of population is not available.

*Included in Tamilnadu from year 2011

Source: TARI\& Telecom Statistic India 2019.

Table No 10: Service Area wise Total Mobile Internet Subscriptions in Rural India from 2015 to 2019 (in Millions)

\begin{tabular}{|l|l|l|l|l|l|l|l|}
\hline Year & 2019 & 2018 & 2017 & 2016 & 2015 & Mean Value & CAGR \\
\hline AP & 19.94 & 12.83 & 12.10 & 9.13 & 8.14 & 12.43 & 19.62 \\
\hline Assam & 5.68 & 5.04 & 4.25 & 3.22 & 3.25 & 4.29 & 11.81 \\
\hline Bihar & 22.62 & 13.51 & 11.91 & 8.87 & 7.94 & 12.97 & 23.29 \\
\hline Delhi & 0.70 & 0.72 & 0.69 & 0.94 & 1.02 & 0.81 & -7.25 \\
\hline Gujarat & 11.44 & 8.26 & 8.26 & 6.05 & 6.46 & 8.09 & 12.11 \\
\hline Haryana & 5.54 & 3.80 & 3.65 & 2.97 & 3.15 & 3.82 & 11.95 \\
\hline HP & 3.21 & 2.04 & 2.10 & 1.75 & 1.63 & 2.15 & 14.52 \\
\hline J \& K & 2.57 & 1.92 & 1.87 & 1.85 & 1.81 & 2.00 & 7.26 \\
\hline Karnataka & 11.93 & 6.69 & 6.37 & 5.54 & 5.31 & 7.17 & 17.57 \\
\hline Kerala & 10.04 & 7.49 & 6.72 & 5.58 & 5.93 & 7.15 & 11.10 \\
\hline Kolkata & 1.53 & 1.00 & 0.76 & 0.55 & 0.44 & 0.86 & 28.31 \\
\hline M P & 15.69 & 6.94 & 7.70 & 6.25 & 5.70 & 8.46 & 22.45 \\
\hline Maharashtra & 20.21 & 12.79 & 11.75 & 9.75 & 9.19 & 12.74 & 17.07 \\
\hline Mumbai & 1.21 & 0.75 & 0.50 & 0.28 & 0.25 & 0.60 & 37.08 \\
\hline North East & 2.78 & 2.38 & 2.22 & 1.97 & 1.91 & 2.25 & 7.80 \\
\hline Orissa & 9.64 & 5.67 & 4.93 & 3.36 & 3.52 & 5.42 & 22.32 \\
\hline Punjab & 7.13 & 4.58 & 4.67 & 4.71 & 4.83 & 5.18 & 8.10 \\
\hline Rajasthan & 15.57 & 9.47 & 8.71 & 7.0 & 7.30 & 9.61 & 16.36 \\
\hline Tamil Nadu & 11.37 & 9.31 & 8.08 & 6.85 & 6.50 & 8.36 & 11.83 \\
\hline U P East & 22.81 & 14.46 & 13.41 & 11.22 & 10.65 & 14.51 & 16.45 \\
\hline UP West & 11.90 & 7.03 & 7.10 & 6.48 & 5.67 & 7.64 & 15.98 \\
\hline West Bengal & 13.49 & 9.14 & 8.80 & 7.64 & 6.90 & 8.19 & 14.35 \\
\hline Total & 227.01 & 145.82 & 136.52 & 111.95 & 107.56 & 145.77 & \\
\hline TARI\& Telecom & Statist & \\
\hline
\end{tabular}

Source: TARI\& Telecom Statistic India 2019.

\section{References}

1. Ashok Jhunjhunwala, Janani Rangarajan, 2011, 'connecting the next billion: Empowering rural India'.

2. Bernstein, L. (1989), Financial Statement
Analysis; Theory, application and Interpretation, Richard D. Irwin, $4^{\text {th }}$ edition.

3. Chitra G Desai, Sahebrao N Shinde, 2009, 'Web based education in India: A changing scenario'. 
4. ParthaGoswami, RajarshiMahapatra and Divyasukananda, 2013,'bridging the digital gap in rural India Vivekddisha: A novel experience'.

5. Prahalad and Hart, (2002), Fortune at the Bottom of the Pyramid, New Delhi: Pearson Publication, New Delhi.

6. R. Rastogi, 'Connecting the next billion web users', presentation at panel discussion, Proc. $20^{\text {th }} \quad$ Int'1 worldwideconf., 2011; www.www2011india.com/panel.html.

7. Sinha, Sidharth (2001), Regulation of Tariffs and Interconnection: Case Studies, India Infrastructure Report 2001, Oxford University Press, New Delhi, India.

8. The Indian telecom services performance indicators, telecom regulatory authority of India (TRAI) 2013.

9. Vyas, V. S. (2002), Changing Contours of Indian Telecom Sector in the Changing Environment, Raj Kapila\& Uma Kapila (Editors), Ghaziabad: Academic Foundation.

10.ZahirKoradia, Aaditeshwar Seth, 2012, 'Ruralnet: Understanding the state of internet connectivity in rural India'.

11.Telecom statistics India-2019, Economics research unit, Department of

Telecommunications Ministry of Communications, Govt. of India, and New Delhi.

12.https://www.ibef.org

13.KPMG.com, ASSOCHAM, August 2017.

14.GSM Mobile Economy Report India, 2016, accessed on 20 July 2017.

15.India Ericsson Mobility Report, June 2017, accessed on 20 July 2017.

16.GSMA India Digital Promise Report, Feb 2017, accessed on 20 July 2017. 